\title{
Development of Brand Community in Iranian New Sport Teams
}

\author{
${ }^{1}$ Amin Rayat ${ }^{*}{ }^{1}$ Mehdi Rayat, ${ }^{3}$ Layla Rayat \\ ${ }^{1}$ Young Researchers Club, Dariun Branch, Islamic Azad University, Dariun, Iran.
}

\begin{abstract}
Background. Through years of spectator interaction, historical moments, heroic performances, and the creation of traditions or rituals, these established teams are excellent examples of brand communities. For newly introduced teams, these elements are likely to be in short supply and many of them struggle to build a community around their sport team.

Objectives. This study explored brand community markers in the context of newly established sport teams.

Methods. We examined whether managers of new sports teams Utilize group experience, organizational history, ritual/traditions and physical facility in their branding strategies. A case study approach was used; featuring both interviews with managers of three newly established Iran professional sports teams and direct observations of games. Results. The findings revealed managers generally considered group experience, history and heritage, ritual/traditions and physical facility to be important, but they failed to implement and apply these mechanisms to an overall marketing strategy. Evidence of the four mechanisms was only apparent on an infrequent and fragmented basis. Promotion of these antecedents was largely absent from the team's branding strategies.

Conclusion. This is the first study to extend the study of brand communities from successful and established brands to new organizations and explored how the different mechanisms relate to this.
\end{abstract}

\section{KEY WORDS: Brand Community, Sport, Group Experience, History and Heritage, Ritual/Traditions, Physical Facility.}

\section{INTRODUCTION}

Through years of spectator interaction, historical moments, heroic performances, and the creation of traditions or rituals, these established teams are excellent examples of brand communities (1). For newly introduced teams, these elements are likely to be in short supply and many of them struggle to build a community around their sport team (2). Consequently, they fail to generate enough revenue when the performance of the new team does not meet the high expectations of the people in their surroundings. This poses the question on how to build a community around a sport team where one did not previously exist.
Brand community research has been focused on successful brand communities such as Jeep (Alexander, Schouten \& Koenig ), Saab (Muniz \& Guinn,), Apple (Muniz \& Schau), and Harley Davidson (Schouten \& Alexander) and these studies explored several markers that are central to a brand community (3).

To extend the perspective of a company as a brand community to a sport team is not farfetched and could provide valuable information on how sport organizations can build communities around their own team. Underwood, Bond and Baer applied these mechanisms to the sport industry and they

*. Corresponding Author:

Amin Rayat

E-mail: rayatamin@yahoo.com 
proposed four strategies for sport teams to build the social identity among their fans: 1. group experiences, 2. history of the organization, 3 . rituals/traditions, and 4.physical facility. To build their case, they found evidence among some of the strongest and oldest brand communities in American sport (Boston Red Sox, University of Alabama Crimson Tide, etc.).

As illustrated by the successful examples of sport teams examined by Underwood and Bond the value of a brand community to a sport team is immense. It allows organizations to better communicate to their consumers and establish rich relationships in which the consumers become heavily involved with the organization. They become co-producers of the brand, who advocate and evangelize the brand to their network (3). As such, brand communities have a strong and positive effect on consumer behavior (4).

However, whether these markers relate to new brand communities remains unclear, both in general marketing as well as in the sport industry. To a certain extent, the focus on brand community has had a post facto focus (e.g. what characterizes these successful brand communities?), rather than an a priori emphasis (e.g. what markers can be used to build a successful brand community?). Therefore, we sought to focus on new brands to examine whether these markers apply to them as well, and whether marketers take them into account while developing their brand.

Newly established teams offer excellent contexts to explore the value of the brand community markers. Based on brand community research, we examined several new teams in different sports that operated in the same geographical market. To this order, we asked the managers of new sports teams what issues they face while marketing a new product and how they utilized brand community markers within their branding strategies. These interviews were triangulated by observations of game day marketing strategies.

Identification with either brands (e.g. Jeep) or consumption activities (e.g. four-wheel driving) is a basis for communities (5). Sports spectating are clearly a mechanism for the development of social relationships. Schouten and Alexander introduced the term "subculture of consumption" to refer to a "distinctive subgroup of society that self-selects on the basis of a shared commitment to a particular product class, brand or consumption activity'. Refining this concept, Muniz and Guinn proposed that a " brand community is a specialized, nongeographically bound community, based on a structured set of social relationships among admirers of a brand. Brand community identification is a process in which a person recognizes their membership of the brand community (6).

Alexander, Schouten, and Koenig study of the "Jeep" brand community at "Camp Jeep" events concluded that highly integrated members of the brand community were genuinely interested in the success of the company. Brand communities are sites where intense brand loyalty is expressed and fostered, and where consumers develop emotional connections with a brand (7).

researchers concluded that brand communities are associated with a more empowered consumer (7). This empowerment prompts firms to treat their customers as partners, providing them with a degree of influence over information gathering and decision making, and cooperating with community members in ways that are mutually beneficial and profitable. This is familiar to the sports industry, where consumers of sport teams are commonly referred to as "members". The value of developing a sense of community around the sport team is eminent, as the sense of community (e.g. team identity) of the member/fan has been seen to impact consumer behavior patterns, such as attendance, media consumption, merchandise sales, and loyalty (8) (9).

Schouten and Alexander noted several markers to what they referred to as a "subculture of consumption'. They recognized a hierarchical social structure within the community based on commitment and authenticity, a set of shared values and/or beliefs, and a unique set of rituals, jargon and other forms of symbolic expressions (5). Muniz and O' Guinn discussed three markers of a brand community (1). The first marker is the consciousness of kind, in which the individuals acknowledge the concept of "we". This 
acceptance of "we" is accompanied by a strong sense of "they", Development of Brand Community 37 which is used to refer to either non-members, or to members of an opposite brand. An important issue within the consciousness of kind is the concept of legitimacy (what Schouten \& Alexander, 1995, refer to as authenticity).

The second marker is focused on the rituals and traditions within the community. These rituals and/or traditions take place in order to celebrate the history of the brand and allow the members to share stories about the brand. Their third marker details the moral responsibility the members feel towards the brand. This involves integrating and retaining new members, and assisting other members in the use of the brand. Underwood, Bond were the first to expand the brand community literature to the world of sport and they explored social identity of sport fans to develop a brand community. Their model proposed four characteristics of the sports service marketplace that encourage consumer identification. The first characteristic they explored is the group experience. They suggested that there may be very few other consumer experiences in which consumer bonding, interaction and affiliation is as intense as it is within the sports market place. Fans bond prior to the game (e.g. within the United States, this is referred to as "tailgating'), and during the game and often feel an intense kinship to their fellow fans. The second characteristic they explored is history (1). History contributes to the identity of many of the world's most valuable brands and those historical references by sport organizations contribute towards increased emotion and identification towards the team. Preliminary research has also suggested that history and heritage are positively associated with revenue generation for professional sports teams (10). To overcome the absence of a playing history, several newly developed teams have successfully associated themselves with the wider history of the sport (11). As Muniz, O' Guinn, Underwood, Bond, and Baer acknowledged the importance of rituals and traditions as a characteristic of brand community. Rituals offer a sports team the chance to develop its brand, enhance the ambience of the game and help promote the game as an event (12).

Rook introduced the idea that the ritual construct could be a vehicle for interpreting consumer behavior. Vincent argued that a culture may form around a brand quickly when a brand is used within some form of consumer ritual; and that if rituals begin to form within a specific consumer group, the corresponding brand is likely to be developing successfully (13).

The facility serves as the most tangible and visual representation of the sports brand, and acts as a distinctive brand attribute. Underwood, Bond, and Baer (2001) were the first to introduce the physical facility as a characteristic of brand community, which might have to do with the fact that they were the first to explore brand 38 Nigel Grant et al. communities within a service industry (e.g. sports teams), rather than a product (e.g. Saab, Harley Davidson, Ducati, Apple, etc.) (14).

Even though these studies have provided us with a detailed overview of what a brand community entails, their research focus has been focused on well-established brand communities surrounding some of the strongest brands of the world. This limits our understanding of what these markers can contribute towards the development of a brand community. Are these markers antecedents for a brand community, or are they outcomes caused by the brand community? Therefore, the aim of this study was to examine whether managers of newly established sports teams consider these markers while establishing their new teams and use these markers within their own marketing strategies. To that end, we restrained from creating deductive categories. In order to fully understand what managers brought forward, we needed to be able to freely consider the meaning of their words and therefore we used the study of Underwood, Bond, and Baer merely as guide while creating the interview. For the interpretation of the managers' responses, we consulted all the brand community studies noted in the literature review.

\section{MATERIALS AND METHODS}

Study Design. The design for this study featured three key components (1) a qualitative 
study, with (2) an exploratory perspective, and (3), investigated through the use of case studies. The study aimed to investigate the presence of both the brand community and Underwood, Bond, and Baer (2001) concepts and their antecedents within the participant organization marketing strategy. Therefore, the study attempted to uncover facts specifically about the environment under investigation rather than making universal or all-encompassing statements about the sports industry as a whole. Rossman and Rallis (2003) proposed that a subjective approach features, for example, the use of case studies, data in the form of words, and aims to compare varying perspectives (15). These attributes are all facets that were employed in the present study. The focus of the study resided in developing understanding of the environment, rather than the testing of theories or creation of universal laws.

The exploratory perspective was partnered by the use of multiple, indepth case studies. The case study is a research strategy focusing on understanding the dynamics present within individual settings. The underlying objective of undertaking case study research is to obtain rich data and depth of understanding, with analysis focusing on organizing data by specific individual cases with the target of in-depth study and comparison (16).

Case studies were also deemed appropriate due to their common and suitable application to qualitative marketing research (17). The advised method to investigate this process within the context of this study is to treat each organization as a single, in-depth case study. A multiple case study design was used because of the number of organizations in volved in the study (13). Rather than examine a single organization and its branding practices, this study sought to provide a greater insight into multiple variations and current trends in new sports team branding. This also contributed improved validity to any conclusions made following the investigative process.

Three case study sites were selected: (a) the Mashhad Padidideh, (b) The Pars Mehr, and, (c) The Kara. Three main reasons underpinned the selection of the case study sites. In the first instance they shared status as newly established teams. Secondly, because the teams were all involved in different sports (and thus in different leagues), but located in the same city, we were able to place their marketing strategies in a broader market context. In many ways, the teams were competing with each other for a fan base and media attention, yet their different sports allowed for significant differences in their marketing strategies. The Padideh were a Football team with a lot of resources and they were able to spend significant resources towards their marketing, while both the Kara (Football) and the Pars Mehr (Volleyball) were very limited to undertake any marketing at all. In addition, while both the Pars Mehr and the Padideh offered a sport that was part of the Iran culture, the Breakers had to find a market for a sport that seemed foreign to most people in their surroundings. Thirdly, both the Kara and the Padideh were part of an Iranian-based league, while the Pars Mehr played in a Iran,Volleybal league.

Table 1 contains an overview of the key characteristics of the three sites indicating their similarities and differences.

Table 1. Characteristics of selected research sites

\begin{tabular}{cccc}
\hline Characteristic & Padideh & $\begin{array}{c}\text { Pars } \\
\text { Mehr }\end{array}$ & Kara \\
\hline Sport type & Football & Voleyball & Football \\
\hline $\begin{array}{c}\text { League } \\
\text { location }\end{array}$ & Iran & Iran & Iran \\
\hline Location & Mashhad & Shiraz & Shiraz \\
\hline $\begin{array}{c}\text { Profit } \\
\text { orientation }\end{array}$ & $\begin{array}{c}\text { For- } \\
\text { profit }\end{array}$ & $\begin{array}{c}\text { Non- } \\
\text { profit }\end{array}$ & $\begin{array}{c}\text { For- } \\
\text { Profit }\end{array}$ \\
\hline
\end{tabular}

Data Collection. Each organization was approached with an initial phone call, introducing the project to the chief executive or marketing manager. While all staff members employed at a sports organization contributes to the development of a brand, it was deemed that management overseeing the marketing of the new brand were in the best position to reflect on this. To that order, two representatives from each team were interviewed.

The interviews were semi-structured. The advantage of this method is that data conforms to the original requirements of the study, but also enables the researcher to view unexpected and interesting data that emerges from individual respondents (18). Managers were asked about 
the challenges they faced, after which they were asked whether they gave special attention to strategies meant to create a sense of community among their fans. When asking for brand community markers, we followed the model of Underwood, Bond, and Baer since their markers were taken from the sports entertainment industry. In order to triangulate the data collected from the interviews, direct observation of the games was used to validate the statements of the managers in regards to their marketing strategies. Wells suggested that direct observation can produce a highly detailed and accurate record of what people actually do compared to what they say. The focus of the observation was not on consumer behavior, but on the environment and what marketing strategies or initiatives were present from each case organization. Five games were attended in total, two each for the Warriors and Breakers and one for the Diamonds. Observation began approximately 45 to 60 minutes prior to the commencement of each game, and the researcher remained behind for 15 minutes following each match.

The researcher completed written documentation of the observed environment and examined activities, promotions, and organizational practices employed by each team. Photographs of the sites were also taken. Specific reference was devoted to examining whether the elements of group experience, heritage, rituals, and any active use of the physical facility were present in the facility in which each team play.

Data Analysis. To analyze the data, coding and organizing followed the approach advocated by O'Leary (14). This process involved: (1) reading and rereading of the data, (2) growing the understanding of the data through notes and memos, (3) organizing and coding data, and (4) searching for patterns to develop and build theories. The technique used throughout the study, in conjunction with the process of coding, was constant comparison. Initially proposed by Glaser and Strauss constant comparison is where the researcher simultaneously codes and analyzes data in order to develop concepts. In undertaking constant comparison, the researcher generally engages in line-by-line or paragraphby-paragraph reading of interview transcripts.
Using this method allows the researcher to continually compare incidents or themes in the data from each text, and subsequently create a theory through refinement and relationship exploration.

Rather than using a numerical coding system, coding took the form of ordering data under headings and theme areas common to the context of the study, and that represented those areas of questioning from the interview.

For example, data relating to the group experience was grouped under an umbrella heading of the group experience. From these initial groupings, data was further divided into more specific categories corresponding to each of the questions used throughout the interview process. Data located that corresponded more appropriately with alternate areas or themes of the interview was coded and grouped accordingly. This was to ensure that data was analyzed within appropriate contexts.

\section{RESULTS}

Challenges for New Sport Teams. Often, managers are so caught up in these issues that long-term strategic planning becomes of secondary importance to them, and acknowledging these challenges can provide a background to brand community development issues .Even though the focus of this research is on the perception of managers on brand community and whether they used the different markers while developing their brands, we deemed it appropriate to first acknowledge the challenges that managers are faced with on a daily basis.

The managers identified many challenges confronting them in their daily work. Most mentioned was the general lack of awareness for what they were trying to accomplish. Both the Kara and the Pars Mehr participated in a niche sport in Iran, receiving relatively little attention from the media, and both worked with small marketing budgets. In addition, both the kara and the Padideh competed in an Iranaian based competition, which Pars Mehr the familiarity of the fans with the Padideh. The awareness issues for the Pars Mehr were confounded by the fact that they were a Volleybal's league, and the lack of interest therein by the Pars Mehr audience. As the Pars Mehr' chairman remarked: “'Awareness 
not only of the pars mehr, but also just awareness of elite sport in terms of Volleyball. . . when the competition is on, people kind of tend to know about it but it's still not in their face enough'. The lack of awareness was further confounded by the location of the three teams. The social culture places more emphasis on participating in active, outdoor activities. Another challenge the managers identified was related to the difficulty of competing against established teams. As new teams to the leagues, all three of them spent time at or near the bottom of the league rankings. The lack of success on the field made it even harder to build their brand and fan base. For both the Pars Mehr and the Kara, this issue was further confounded by the perceived quality of the competition in general. As noted earlier, The Pars Mehr struggled with this because of the gender of their players. The Kara struggled with this because the Iran Football League was perceived as a second-rate competition internationally. Finally, each of these teams faced a high turnover in personnel. Of the six managers interviewed, three mentioned they were relatively new to their organization, and that they were trying to change things as they saw fit. In fact, one year before this data collection, the Kara got a new owner who changed the entire management team. This created a discontinuity in their marketing strategies that was of great consequences to their use of the brand community markers.

Brand Community Markers (The Pars Mehr). This severely limited their marketing activities, and its capabilities to initiate new projects. Of the three teams, the Pars Mehr formed the organization with the smallest budget..As the general manager acknowledged, they did not have a particular budget for marketing and the only marketing initiative he could recall that required a budget was the production of 15,000 posters, and several large banners. Nevertheless, of the three teams, the Pars Mehr were the ones who had most clearly defined their target market, namely participants in the sport of volleyball and they centered their marketing efforts on the community of Volleyball. Rather than focusing themselves on building their own community, they realized that their existence was based on their ability to become an essential part of the Volleyball participant community. As the general manager mentioned: "I suppose it's everything to a degree because we are marketing to a community of people which is the Volleyball playing community." He calculated that if the Volleyball league were able to attract every Volleyball participant in the nation (by his estimation 120,000 women) to one game each, every seat in the league would be sold out.

However, even though the Pars Mehr had recognized their community, the way they reached out to this participant community was locked within traditional marketing strategies. Their main strategy was sending out free tickets to schoolchildren, while their parents paid for their tickets. When asked about the different markers in brand community, their responses varied. They recognized the value of group experience, but did not offer any evidence of strategies to enhance the group experience of their fans. At some point, they tried to provide social facility after the game, but their current facility would not allow for that, and they were not exploring other opportunities. Their perception was that since their fans were all participants in Volleyball, they did not need this social facilitation. Their main group experiencerelated marketing strategy was an end of the season party, called the Volleyball. The managers also recognized the value of the history of the team, but were uncertain to what degree they should use it. For one, they felt they had underperformed, as they were unable to win any titles and had one of the lowest winning percentages in the league. They also felt they were limited in showcasing their history to their fans since they did not have any materials to hand out to their fans, aside from the posters (which did not contain any historical information). At the moment of the data collection they were writing up the history of the organization, which they intended to put on their website. This search for identity was driven by their perception that they were still relatively anonymous to most people in Shiraz. Since their inception, the Pars Mehr had relocated to new facilities on three occasions, which severely limited their ability to build some roots and history in one place. Our observations supported this notion, as the arena in which they played their game seemed rather anonymous and not 
reflective of the Pars Mehr' community. When asked about traditions, they acknowledged the importance, but mainly relied upon their fans to start particular traditions and/or rituals. The only tradition the managers acknowledged that was initiated by them was a particular song that they played during the last break ('We Will Rock You'*Queen). One of the more noticeable rituals observed, initiated by a small group of fans, was a group of young adult males who dressed up as cheerleaders when attending games. In a predominantly female crowd they were very noticeable and the general audience responded very well to them. When one of the managers was asked about them, he mentioned that he was aware of them, and he recognized their value as an opportunity to create a tradition. This was to be achieved by providing them with an official team kit, and showcasing them via images and stories on the website.

The physical facility did not play a large role in the development of their brand. Game day observations only identified minimal acknowledgment of the facility. Within the stadium, there were a number of banners identifying the facility as the "home" of the Pars Mehr.

Brand Community Markers (The Kara). While the Pars Mehr had a clearly defined community they wanted to be a part of, and positioned their brand identity accordingly, the Kara faced a less obvious situation and was still searching for an identity. The Kara was the youngest organization of the three sport teams, and arguably had the biggest challenges ahead of them. They recently hired a new marketing manager, who had been at the job for a month and a half when interviewed. He acknowledged he had no idea what the Kara did in the past, and felt he started from ground zero. His main priority was building a consistent brand. As he stated: "I think the first step in getting your message out there is to make sure that all of your components and all your marketing, everything you do put out in the public is the same message and the same image, and the same consistency with it." To that end, most of his work was focused on creating a brand, through a consistent logo, a slogan, core colors and a unified message. When asked about the different brand community markers, he responded in terms similar to the Pars Mehr, that the brand markers appear to be valuable but they did not actively build their brand around the development of the markers, preferring instead to utilize a more traditional marketing paradigm. To the question probing what they did to foster the group experience of their fans, the marketing manager responded: "To develop a strong following with the Kara is just what I have been saying the whole time; To provide them with the best possible entertainment I can to keep them entertained throughout the whole game." When we attended the games, this could be observed from the stands. During most time-outs, some kind of promotion or activity was going on, varying from throwing $t$-shirts into the stand, cheerleaders performing, trivia questions, to the so-called "dot races' (a video game in which three objects race against each other*the audience has to guess who wins). Even though these activities might contribute somewhat to the group experience, the Kara failed to recognize that these activities are mainly promotional activities in which (nearly all of) the fans remained passive. In fact, it could be argued that these activities might actually distract from a more active dialogue between fans, thereby curtailing the group experience. History was not seen as important at all. As one of the managers stated: "I guess I don't, because I am not relying on anything we have done in the past for this year. We are starting from scratch." This had not only to do with the lack of success in the previous years, but also with the complete overhaul of the management staff in the organization that came with the new ownership. A similar situation arose when we asked them about their rituals and traditions. The marketing manager recognized the value of traditions and rituals and had various plans to initiate new traditions or rituals. When asked more in-depth what he was planning he mentioned that he wanted to see what the crowd responded to well, before he decided that.

Brand Community Markers (The Padideh). Of the three organizations, the Padideh were the most established sport team. They survived their turbulent first years (they had a controversial ownership change in 2000), and were comfortable about the direction their brand was heading in. they were able to position 
their brand as Iranian team, and even though they played football, they were still able to acquire interest from Iran dominant Football community. The Padideh name allowed them to explore the multi-cultural character of Iran society and demonstrated their Maori heritage, a theme common to many of their marketing initiatives. This was particularly useful as the sport of Football league was popular among the ethnic minorities in Iran. When asked about the markers of brand community, the Padideh's managers felt strongly that each of the elements was important to them and that they were present in the Padideh' brand community. For group experience, the Padideh utilized several initiatives, almost always in cooperation with sponsors. As the football manager stated: "primarily again, it is all done through our sponsors. So again, we kill two birds with one stone. We get the interaction with the fans, and then we fulfill sponsorship obligations as well." The main initiative was called the "One Tribe", a community that fans could join that was funded by Vodafone (the Warriors' main sponsor). One Tribe's main focus was on promotional strategies that were aimed to bring the fans closer to the team (e.g. special access, gifts, free tickets, etc.).

Aside from One Tribe, players of the Padideh were involved in activities for other sponsors such as Lion Breweries (the players went from pub to pub to promote the beer). What remained unclear in the discussions with both managers is how the Padideh profited from these initiatives, or whether these activities were mainly beneficial for the sponsors. The Padideh did have visible pockets of fan groups spread out over the stadium, and the marketing manager knew of their existence, but acknowledged they did little to support them. Rituals seem to play a small role in the marketing strategy of the Padideh. The only team-initiated ritual the marketing manager mentioned was that they were bringing back the drummers, a ritual that originally had been a part of their games and that emphasized their Polynesian heritage. The reason it was cancelled was because the previous manager felt it to be too loud. The fact that the current marketing manager had to bring back this activity, suggests that this activity cannot be yet qualified as a ritual. The manager did mention some smaller fan-initiated rituals (e.g. face painting, chants, etc.), but the team did not undertake anything to support that kind of behavior. Unlike the Pars Mehr and the Kara, the Padideh did have a home stadium and had been able to play all their games in the same place. Their facility was not instrumental to their view of community, and they approached the operation of the facility from a traditional point of view; creating the best facilities for the fans and offering them the best service quality.

\section{DISCUSSION}

The aim of this study was to examine the brand community work in the context of newlyestablished sports brands. Even though the managers of all three teams believed the group experience, the history and heritage (to a limited extent), the rituals and traditions, and the physical facility to be important to brand development, in many instances they did not make full use of it and did not initiate marketing strategies to encourage their development (see Table 2 for an overall overview). While the organizations were aware of the precursors to brand community or social identification, and mentioned future plans to initiate development of each antecedent, currently there was minimal practice or development.

Consequently, strategies towards building the brand through these four mechanisms were fragmented or non-existent. Often the managers did not even recognize certain marketing activities as contributing to one of the four mechanisms. In many ways the managers perceived their brand to be weak, and were hesitant to market their current brand, hoping that future improvement would allow them to do so. For instance, all the managers perceived a general lack of history, but their appreciation of history was limited. They focused on the history they did not have (e.g. championships), rather than history they did have, such as great players, individual highlights or simply the amount of games played. Sport teams such as the Chicago Cubs have shown that a team does not necessarily have to be successful to implement history in their marketing strategies. 
Table 2. Brand community strategies of the Iran sport teams

\begin{tabular}{|c|c|c|c|}
\hline & The Kara & The padideh & Pars Mehr \\
\hline \multirow[b]{2}{*}{ Marketing history } & No strategies & No strategies & No strategies \\
\hline & & & $\begin{array}{c}\text { Marketed the } \\
\text { history of } \\
\text { Voleyball league }\end{array}$ \\
\hline Marketing traditions/rituals & No strategies & & $\begin{array}{c}\text { Fan initiated } \\
\text { chants }\end{array}$ \\
\hline Marketing the group experience & $\begin{array}{l}\text { Game promotions } \\
\text { (e.g. t-shirt give } \\
\text { away, dot races) }\end{array}$ & One Tribe & $\begin{array}{c}\text { End of year } \\
\text { event }\end{array}$ \\
\hline Marketing the facility & $\begin{array}{c}\text { No strategies } \\
\text { Played in } \\
\text { different facilities }\end{array}$ & & No strategies \\
\hline \multirow{5}{*}{ Challenges within marketing } & $\begin{array}{c}\text { No awareness of } \\
\text { team }\end{array}$ & Lack of success & $\begin{array}{c}\text { No } \\
\text { awareness of } \\
\text { team }\end{array}$ \\
\hline & Small budget & $\begin{array}{l}\text { High turnover } \\
\text { of personnel }\end{array}$ & No budget \\
\hline & Lack of success & $\begin{array}{l}\text { Change of } \\
\text { ownership }\end{array}$ & $\begin{array}{l}\text { Lack of } \\
\text { success }\end{array}$ \\
\hline & $\begin{array}{l}\text { Change of } \\
\text { ownership }\end{array}$ & & $\begin{array}{l}\text { Low quality } \\
\text { league }\end{array}$ \\
\hline & $\begin{array}{c}\text { Low quality } \\
\text { league }\end{array}$ & & \\
\hline
\end{tabular}

For new sports teams, managers may be of the opinion that their brand does not radiate a great deal of social identification, nor possesses a large community of loyal consumers. However, it is advised that a new team carefully considers the brand community concept, and regards themselves as the center to a community from the time when the team was created. There are clear benefits for those organizations capable of facilitating increased interaction and a sense of community between and amongst its consumers.

Realization and preservation of brand communities within the professional sport environment or consumer products has the ability to offer social interaction and personal sanctuary, contributing to the never-ending human search for belonging.

This study is an initial investigation of how new organizations are using the brand community markers to enhance the community of their own brand. As such, the findings of these case studies are somewhat limited, but they do open the door for further research. For this study, the researchers chose to interview the managers and triangulate the data with observations.

The view of the fans on the topic of brand community remains unexplored and should be included in any follow up study. Each of the four mechanisms deserves more in-depth examination in different settings and further exploration should give more insight on how to effectively implement these strategies into the marketing strategy of a sports team. Finally, the researchers recommend using experimental designs to examine the effectiveness of these four mechanisms in more detail.

However, despite these limitations, we would like to argue that sport team managers do little to facilitate and develop the brand community of their team. Those markers of brand community that were present at (either one) of the three sport teams, was often initiated by fans (e.g. the male cheerleaders for the Pars Mehr) or created by the team, without acknowledging them as such, and thereby sensitive to organizational change (e.g. the Warriors). When community development was discussed, the managers relied more upon external communities than on their 
own community, and had to yet to figure out that in order to attract this community, they needed to represent that community. The Pars Mehr relied upon the Volleyball participants; the Paddideh relied upon the Football league participants, fans of rugby in general (those who like Football union so much, they would also watch the other code of Football) and the national (Iran) and ethnic identity of their fans. Even though participant communities have been regarded as valuable target markets for passive sport consumption, as they understand the intricacies of the game, the fact that they play the sport does not automatically lead them to fandom. For instance, while soccer is the most widely played sport in the United States, it is still not among the most widely watched sports in the United States. Strategies to successful convert a participant-based community, into a passive sport community remain unexplored and should be the topic for future research. The Kara struggled to connect to any external community, and their main focus was still on their own identity. Most of the traditional sport teams who were established decades (or centuries) ago, came into existence as a direct result of an external community, or were able to take advantage of a market that was more conducive for community building (Heere \& James, 2007), and as such, the Pars Mehr and the Padideh seem to head in the right direction. However, in the current marketplace where many of the sources for communities are no longer geographical, new sport teams are struggling to build a community around the team. In the case of the new sport teams in the Iran, they have yet to effectively build a marketing strategy to do so. It is argued by the researchers, that for these teams to be successful on a long-term basis it will be essential to develop an overall marketing strategy in which group experience, the history and heritage, the rituals and traditions, and the physical facility play a larger role than they do today.

\section{CONCLUSION}

For sport managers, building a marketing strategy around the markers of brand community can be a powerful tool to connect to their fans. The reliance upon a traditional marketing strategy (that emphasizes the strengths and weaknesses of the marketing mix) is often detrimental to the new sport team. Often, these teams have an inferior product compared to their more established competitors. Nevertheless, in order to compete, they have to price their product following league averages, often resolving in product price incongruence. By putting the brand community marketing strategy central to their overall strategy, marketers are able to circumvent the poor Marketing mix, and create a community in which the performance of the team is secondary to the overall sense of community fans perceive from becoming a part of the team. Once fans perceive themselves as community members they become more loyal to the brand (e.g. more resistant to bad performances), they create their own narrative surrounding the brand, in which mere play-off wins are celebrated as championships (e.g. South Korea and their semi-final performance during World Cup 2002), and ordinary players become heroes, and they will serve as brand advocators in their own network $(1,3)$. Within this quest of converting fans into community members, the different markers proposed by brand community theorist can play a central role. Creating group experiences before and/or after the game gets fans more involved with the community and can distract from any poor performance. History can play a similar role, as it reminds fans of better times. Even though most of these new sport teams have relatively unsuccessful pasts, even minor victories and great highlights can serve as a powerful tool for identity with the community. Additionally, external communities can serve well in this capacity, as it allows sport teams to use more elaborate communities that have more meaning to their fans (2). Recognizing the value of traditions and rituals seems crucial as well. Both the Padideh (the Polynesian drummers) and the Pars Mehr (male cheerleaders) had faninitiated rituals, and cherishing these rituals (as the Pars Mehr's manager acknowledged) can form another point of identification that distracts from any poor performance. Finally, the physical facility can accentuate these different markers by providing the fans with a sense of "home". Two of the teams were still doubtful about which arena they should call their home facility, leading to a situation where the facility seemed 
fairly anonymous and therefore, it did not provide the fans with a sense of community.

To conclude, this study reaffirms comments by Algesheimer, Dholakia, and Herrmann, who suggest that brand communities offer a fresh effective and vital approach to building brands in the present-day unresponsive marketing environment. Realization and preservation of brand communities within the professional sport environment or consumer products may have the ability to offer social interaction and personal sanctuary, contributing to the never-ending human search for belonging. While the overriding argument of this thesis resides in the importance of brand community and social identification techniques to brand development and management, the creation of brand community has the ability to transcend simple marketing objectives.

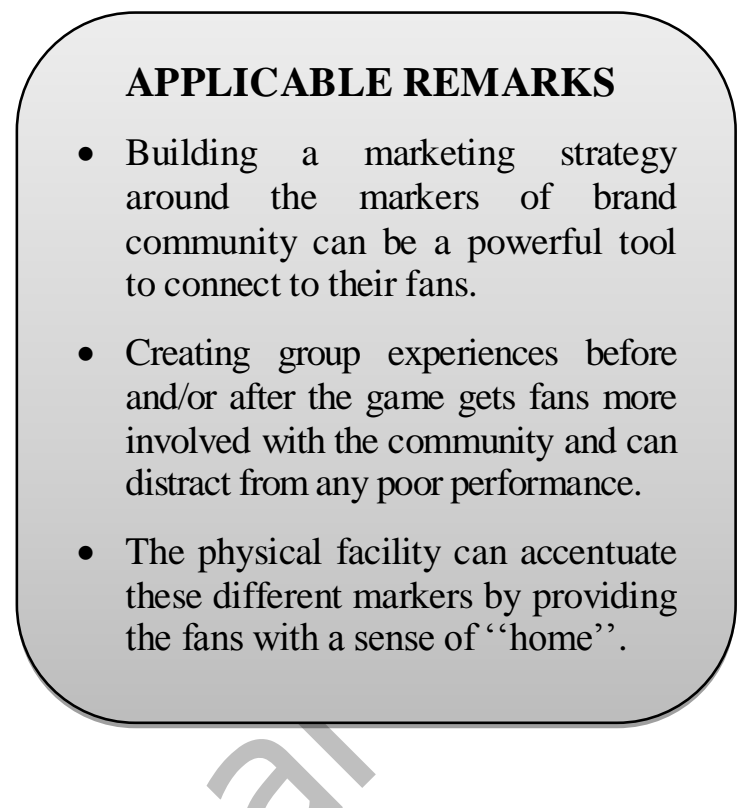

\section{REFERENCES}

1. Muniz Jr AM, O’Guinn TC. Brand community. Journal of Consumer Research. 2001;27(4):412-32.

2. Heere B, James JD. Sports teams and their communities: Examining the influence of external group identities on team identity. Journal of Sport Management. 2007;21:319-37.

3. Muniz Jr AM, Jensen Schau H. Religiosity in the abandoned Apple Newton brand community. Journal of Consumer Research. 2005;31:737-47.

4. Carlson BD, Suter TA, Brown TJ. Social versus psychological brand community: The role of psychological sense of brand community. Journal of Business Research. 2008;61(4):284-91.

5. McAlexander JH, Schouten JW, Koenig HF. Building brand community. Journal of Marketing. 2002;66(1):3854.

6. Algesheimer r, Dholakia UM, Herrmann A. The social influence of brand community: Evidence from European car clubs. Journal of Marketing. 2005;69(3):19-34.

7. Bagozzi RP, Dholakia UM. Antecedents and purchase consequences of customer participation in small group brand communities. International Journal of Research in Marketing. 2006;23(1):45-61.

8. Gwinner K, Swanson SR. A model of fan identification: Antecedents and sponsorship outcomes. The Journal of Services Marketing. 2003;17(3):275-94.

9. Madrigal R. The influence of social alliances with sports teams on intensions to purchase corporate sponsors' products. Journal of Advertising. 2000;29(4):13-24.

10. Delanty G. Community. London: Routledge. 2003.

11. Haimes G. Organizational culture and identity: A case study from the Australian Football League. Perth, Australia: Victoria University; 2005.

12. Richelieu A. A brand new world for sports teams. (Ed.) IBGP, editor: Sharing best practices in sport marketing: The sport marketing association's inaugural book of papers.

13. Vincent L. Legendary brands: Unleashing the power of storytelling to create a winning marketing strategy. Chicago: IL: Dearborn Trade Publishing; 2002.

14. Dickson G, Arnold T, Chalip L. League expansion and interorganisational power. Sport Management Review. 2005.

15. Rossman GB, Rallis SF. Learning in the field: An introduction to qualitative research. 2nd, ed, editors: CA: Sage; 2003.

16. Patton MQ. Qualitative research \& evaluation methods. 3, editor. Thousand Oaks: CA: Sage; 2002.

17. Buonamno AC, Mussino a. Participation Motivation in Italian Youth Sport. 1995;9(The Sport Psychologist):26581. 